\title{
DOWNWARD MOVEMENT OF SOIL ORGANIC MATTER AND ITS INFLUENCE ON TRACE-ELEMENT TRANSPORT $\left({ }^{210} \mathrm{~Pb},{ }^{137} \mathrm{Cs}\right)$ IN THE SOIL
}

\author{
HELMUT DÖRR and K O MÜNNICH \\ Institut für Umweltphysik der Universität Heidelberg \\ Im Neuenheimer Feld 366, 6900 Heidelberg, FRG
}

\begin{abstract}
Data on depth distribution and ${ }^{14} \mathrm{C}$ content of soil organic carbon, and on soil $\mathrm{CO}_{2}$ production in forest ecosystems are presented and discussed. Downward movement and turnover of soil organic matter is estimated from a box chain model. The downward transfer velocity of soil organic material depends on the litter material composition and on the annual rate of microbial decomposition. Depth distribution of ${ }^{210} \mathrm{~Pb}$ and ${ }^{137} \mathrm{Cs}$ was measured. The identical transfer velocity of ${ }^{210} \mathrm{~Pb}$ and soil organic material suggests that lead transport is due to movement of the organic material itself. Lead in organic-rich soils obviously is bound rather tightly to the organic carrier by ion exchange or organic complexing. ${ }^{137} \mathrm{Cs}$ migration depends on the turnover and downward movement of soil organic material. Results suggest that cesium is not transported only by the downward movement of solid organic matter, but, due to chemical exchange between the organic and hydrous phases, travels faster than organic matter.
\end{abstract}

\section{INTRODUCTION}

In a forest ecosystem, organic material is added to the soil by annual litter fall. In the steady state, sedimentation of organic carbon at the soil surface is balanced by microbial decomposition of soil organic material in the entire depth profile. However, forest soil organic matter is not a very well-mixed reservoir. ${ }^{14} \mathrm{C}$ depth profiles show that organic material is younger at the top than at the bottom of the soil. Let us assume that the soil organic carbon reservoir is made up by at least fast and slow decomposable components. The fast, and thus young, component is located in the top soil layer, whereas in deeper layers, the slow and old component predominates (O'Brien \& Stout, 1978; Harkness, Harrison \& Bacon, 1986; O'Brien, 1986). The turnover time of the fast $(1 \mathrm{yr})$ and the slow $(100 \mathrm{yr})$ components and the downward velocity of soil organic matter can be adequately adjusted to model the ${ }^{14} \mathrm{C}$ depth distribution in a forest soil to a satisfactory degree (Dörr \& Münnich, 1986).

The transport of natural and anthropogenic trace elements in the soil is retarded by adsorption, ion exchange and complexing. The specific surface as well as the ion exchange and complexing capacity of organic material exceeds that of clay and sand. Thus, trace elements, which are deposited on the soil surface where soil organic material is maximal, are preferentially attached to organic material.

We investigate here the influence of soil organic matter transport on the downward movement of lead and cesium. The downward velocities of organic material, lead and cesium are evaluated by simultaneous modeling of $\mathrm{C}_{\text {org }},{ }^{14} \mathrm{C},{ }^{210} \mathrm{~Pb}$ and bomb ${ }^{137} \mathrm{Cs}$ profiles taken from undisturbed forest soils of south Germany. The turnover of soil organic matter is determined from soil $\mathrm{CO}_{2}$ production measurements. 


\section{EXPERIMENTAL METHODS}

\section{Sampling}

Soil $\mathrm{CO}_{2}$ production is determined weekly by direct $\mathrm{CO}_{2}$ flux measurement and by calculating the $\mathrm{CO}_{2}$ flux from concentration profiles of $\mathrm{CO}_{2}$ and ${ }^{222} \mathrm{Rn}$ in soil air combined with direct ${ }^{222} \mathrm{Rn}$ flux measurements (Dörr \& Münnich, 1987a). Top soil temperature $(0-15 \mathrm{~cm})$ is also measured.

The soil cores are taken in metal cylinders, $12 \mathrm{~cm}$ long, $72 \mathrm{~cm}^{2}$ cross-section, and cut into slices $1 \mathrm{~cm}$ thick. ${ }^{210} \mathrm{~Pb},{ }^{226} \mathrm{Ra},{ }^{134} \mathrm{Cs}$ and ${ }^{137} \mathrm{Cs}$ activity is measured by $\gamma$-spectroscopy. Samples were "cleaned" of living roots. Carbonates and the soluble organic fraction were removed by washing the sample in $0.1 \mathrm{~N} \mathrm{HCL}$ and $1 \mathrm{~N} \mathrm{NaOH}$. Soil organic carbon content was determined from the $\mathrm{CO}_{2}$ after combustion or by the weight loss after heating the sample at $800{ }^{\circ} \mathrm{C} .{ }^{14} \mathrm{C}$ samples were processed and measured in the Heidelberg ${ }^{14} \mathrm{C}$ laboratory. Part of the samples were prepared by "fast bomb combustion" (Dörr, Kromer \& Münnich, 1988).

\section{Sites}

Samples were taken in ca $20 \mathrm{~km}$ radius around Heidelberg. Four stations (M1 - M4) were set up ca 15km south of Heidelberg. M1, M2 and M3 are located in the Rhine River valley. The maximum distance between M1M3 is $1 \mathrm{~km}$. M4 is ca $5 \mathrm{~km}$ east at the hillside bordering the valley.

M1 is on top of a formerly shifting sand dune. At the beginning of this century the sand dune was forested with beech and spruce. The carbonate content in the dune topsoil is ca $5 \%$ (by weight); soil pH $\simeq 7.7$.

M2 is on the bank of a former drainage ditch. Until the beginning of this century, the site was frequently flooded in seasons of high precipitation; thus, the sandy sediments were covered with an organic rich, loamy layer, ca $80 \mathrm{~cm}$ thick. The site is now forested with oak, maple and beech. The carbonate content of the topsoil layer is ca $4 \%$ (by weight); soil $\mathrm{pH} \simeq 8$.

$\mathrm{M} 3$ is in a mixed beech/spruce forest; the sandy soil contains no carbonates here; soil $\mathrm{pH} \simeq 3.5$. M4 is in a spruce forest on clayey and loamy soil. The carbonate content is $<1 \%$ (by weight); soil $\mathrm{pH} \simeq 5$.

\section{RESULTS AND DISCUSSION}

\section{Decomposition of Soil Organic Matter}

Soil $\mathrm{CO}_{2}$ is produced by microbial decomposition of soil organic matter and root respiration. From ${ }^{14} \mathrm{C}$ measurements in soil respiration $\mathrm{CO}_{2}$ and soil $\mathrm{CO}_{2}$ concentration measurements, we estimate the contribution of root respiration at site $\mathrm{M} 3$ to be only a few percent of the total $\mathrm{CO}_{2}$ production (Dörr \& Münnich, 1986). We assume that this also holds true at M1, M2 and $\mathrm{M} 4$, due to similar vegetation density and depth distribution of $\mathrm{CO}_{2}$ source strength. At all sites, the soil $\mathrm{CO}_{2}$ source strength decreases exponentially with depth with a relaxation depth of ca $10 \mathrm{~cm}$.

Figure 1 shows the annual variation of soil $\mathrm{CO}_{2}$ production, given as monthly means. Soil $\mathrm{CO}_{2}$ production is correlated with soil temperature (Dörr \& Münnich, 1987a). The annual means of $\mathrm{CO}_{2}$ flux and soil temper- 


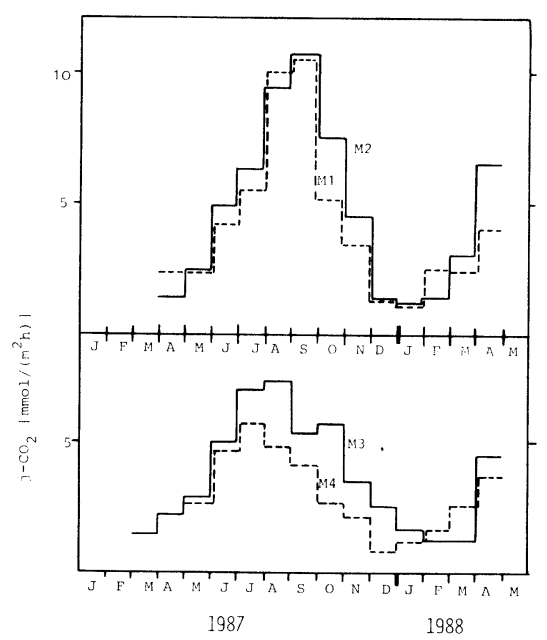

Fig 1. Annual variation of soil $\mathrm{CO}_{2}$ production at the quoted sites

ature are given in Table 1 together with the slope and the correlation coefficient of the $\mathrm{CO}_{2}$ flux - soil temperature regression line.

At M1 and M2, the annual soil $\mathrm{CO}_{2}$ production is ca $30 \%$ higher than at M3 and M4, indicating reduced microbial activity at low soil $\mathrm{pH}$ at $\mathrm{M} 3$ and M4 and higher annual carbon input to the soil at M1 and M2. This is supposedly due to the comparative abundance of deciduous trees, which have a higher standing crop of annually produced leaf biomass than coniferous trees. Table 1 lists the relative contribution of leaves, needles and branches to the annual litter fall reflecting the abundance of deciduous trees at M1 and M2. Higher annual $\mathrm{CO}_{2}$ flux at M1 and M2 (Table 1) cannot only be due to higher soil temperature. With an average temperature dependence of $0.6 \mathrm{mmol} /\left(\mathrm{m}^{2} \mathrm{~h}\right) /{ }^{\circ} \mathrm{C}$ the soil $\mathrm{CO}_{2}$ flux increase would be only ca $10 \%$ for a $1^{\circ} \mathrm{C}$ higher temperature. The different soil temperature is supposedly due to the predominance of deciduous or coniferous trees, respectively, at the specific site. The soil becomes more shaded and its temperature decreases with more coniferous trees, while in a deciduous forest more solar radiation usually is transmitted to the soil.

\section{Turnover and Downward Movement of Soil Organic Matter}

A simple, chromatographic box model describes the movement and turnover of soil organic matter (Dörr \& Münnich, 1986). Total carbon input to the soil is subdivided into a fast component, $\mathrm{j}_{1}$, with a residence time of $\tau_{1}=1 \mathrm{yr}$ and a slowly decomposable component, $\mathrm{j}_{2}$, with a residence time of $\tau_{2}=100 \mathrm{yr}$. The model is run with a time step of $1 \mathrm{yr}$ for a total of 100 yr (M1 \& M2) and of $300 \mathrm{yr}$ (M3 \& M4), respectively, according to the age of the forest ecosystem under investigation (see Sites), to reach a steadystate $\mathrm{C}_{\text {org }}$ profile and for a total of $30 \mathrm{yr}$ (stärting in 1957) to calculate the ${ }^{14} \mathrm{C}$ profile using the known contemporary ${ }^{14} \mathrm{C}$ content of the atmosphere (Levin et al, 1985). The box height, $\mathrm{H}$, simulating statistical fluctuation in the 
TABLE 1

Comparison of data obtained at sites M1, M2, M3 and M4

\begin{tabular}{lcccc}
\hline & M1 & M2 & M3 & M4 \\
\hline $\mathrm{j}\left(\mathrm{gC} / \mathrm{m}^{2} \mathrm{a}\right)$ & 470 & 490 & 375 & 340 \\
$\mathrm{I}\left(\mathrm{kgC} / \mathrm{m}^{2}\right)$ & 3.5 & 4.0 & 16 & 10 \\
$\mathrm{~T}\left({ }^{\circ} \mathrm{C}\right)$ & 10.2 & 10.1 & 9.8 & 9.4 \\
\hline $\mathrm{m}\left(\mathrm{mmol} /\left(\mathrm{m}^{2} \mathrm{~h} /{ }^{\circ} \mathrm{C}\right)\right)$ & .65 & .80 & .59 & .28 \\
$\mathrm{~T}_{0}\left({ }^{\circ} \mathrm{C}\right)$ & -2.6 & -4.9 & -2.8 & 0.7 \\
$\mathrm{r}$ & .65 & .73 & .97 & .81 \\
\hline $\mathrm{j}_{1}\left(\mathrm{gC} /\left(\mathrm{m}^{2} \mathrm{a}\right)\right.$ & 420 & 450 & 225 & 220 \\
$\mathrm{j}_{2}\left(\mathrm{gCC} /\left(\mathrm{m}^{2} \mathrm{a}\right)\right.$ & 50 & 50 & 150 & 120 \\
\hline$\%$ leaves & 70 & 90 & 50 & 0 \\
$\%$ needles & 20 & 0 & 45 & 100 \\
$\%$ branches & 10 & 10 & 5 & \\
\hline $\mathrm{w}_{\text {org }}(\mathrm{mm} / \mathrm{a})$ & $1.6 \pm .4$ & $1.2 \pm .3$ & $.6 \pm .2$ & $.8 \pm .2$ \\
$\mathrm{w}_{\mathrm{Pb}}(\mathrm{mm} / \mathrm{a})$ & $1.6 \pm .4$ & $1.0 \pm .3$ & $.5 \pm .1$ & $.6 \pm .2$ \\
$\mathrm{w}_{\mathrm{cs}}(\mathrm{mm} / \mathrm{a})$ & $2.4 \pm .2$ & $2.3 \pm .2$ & $1.7 \pm .2$ & $1.8 \pm .2$ \\
\hline
\end{tabular}

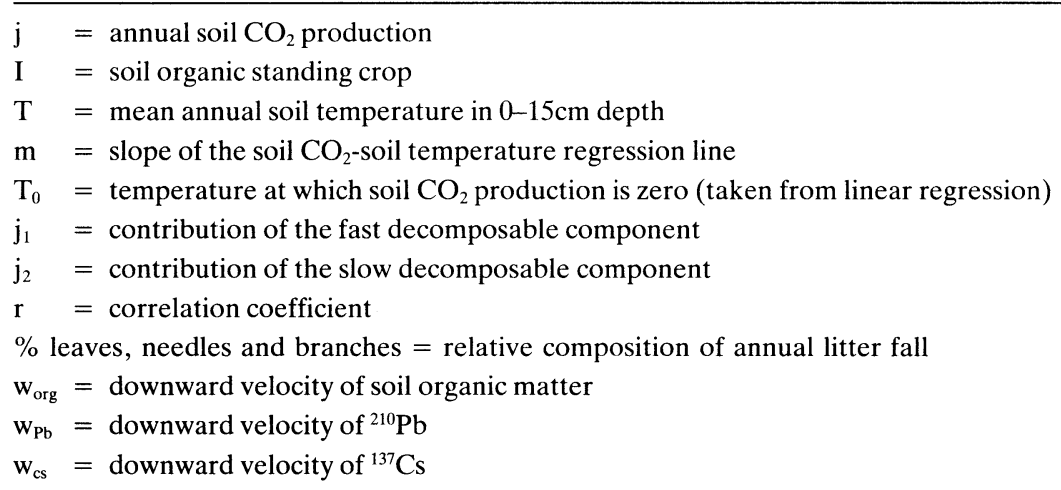

downward movement, is $\mathrm{H}=1 \mathrm{~cm}$ for the profiles $\mathrm{M} 1, \mathrm{M} 2$ and $\mathrm{M} 3$, and $\mathrm{H}=2 \mathrm{~cm}$ for profile $\mathrm{M} 4$.

Figure 2 shows the depth distribution of organic carbon content $\mathrm{C}_{\mathrm{org}}$ and $\Delta^{14} \mathrm{C}$ at M1, M2 and M4, together with the calculated profiles. $\mathrm{C}_{\mathrm{org}}$ and $\Delta^{14} \mathrm{C}$ profiles at M3 ("SA") are shown by Dörr and Münnich (1986). $\mathrm{C}_{\mathrm{org}}$ and ${ }^{14} \mathrm{C}$ profiles can be reproduced satisfactorily using the values $\mathrm{j}_{1}, \mathrm{j}_{2}$ and $\mathrm{w}_{\mathrm{org}}$ from Table 1 . To reproduce the $\Delta^{14} \mathrm{C}$ profile at $\mathrm{M} 2$, a "background" of carbon with a ${ }^{14} \mathrm{C}$ content of $96 \%$ modern is assumed due to sedimentation of formerly organic-rich loam at M2.

Subdivision of the total carbon input gives ca $10 \%$ contribution of the slow component at M1 and M2 and ca 40\% at M3 and M4. Under the assumption that leaf decomposition contributes primarily to the fast component, whereas needles and branches mainly feed the slowly decomposable 
component, higher contribution of the slow component at M3 and M4 is explained by a larger fraction of needles and branches in the litter fall and by lower soil $\mathrm{pH}$ and, thus, reduced microbial activity at these sites (see Table 1).
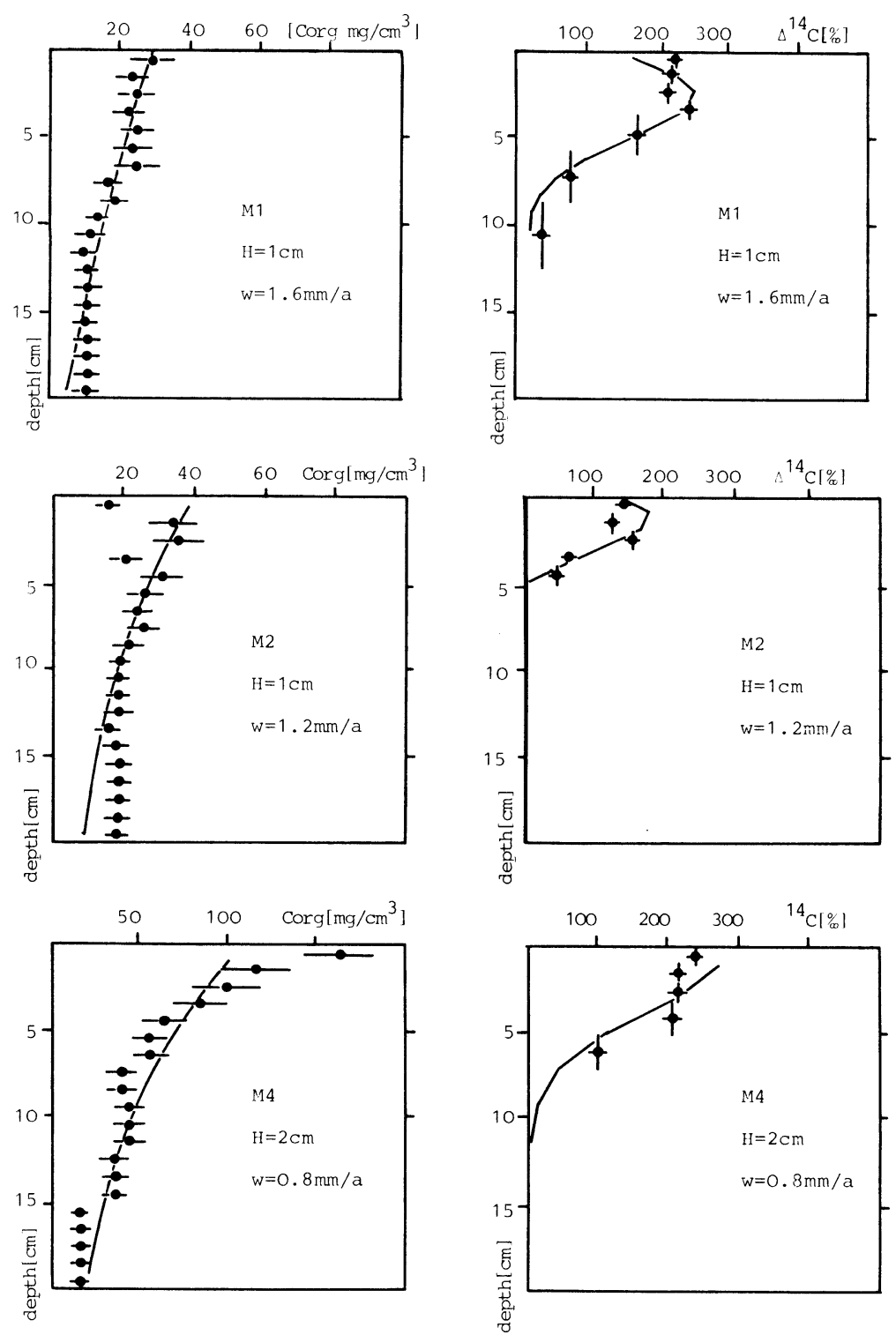

Fig 2. Depth distribution of $\mathrm{C}_{\mathrm{org}}$ and ${ }^{14} \mathrm{C}$ and calculated profiles. Model parameters are given in the diagrams. 
The downward movement of organic material at M1 and M2 is about twice as fast as at sites M3 and M4 ( $\mathrm{cf}_{\text {org }}$ in Table 1). The higher downward velocity at M1 and M2 than at M3 and M4 can be explained by greater input of organic matter to the soil at M1 and M2, and by the fact that the slowly decomposable soil carbon reservoir $\left(\tau_{2}=100 \mathrm{yr}\right)$ has not yet reached a steady state due to the comparatively young age of this forest ecosystem. The consequence of a higher carbon input and disequilibrium between input and decomposition is a secular increase of soil carbon standing crop; this can also be interpreted by a higher steady-state sedimentation rate or a faster downward movement of the bomb ${ }^{14} \mathrm{C}$ peak. Comparison of total soil organic standing crop I at M1/M2 and M3/M4 (see Table 1) supports the assumption that the soils at M1 and M2 are not yet in a steady state with respect to the slow carbon reservoir (with a residence time of $1 \mathrm{yr}$, the fast reservoir practically does not contribute to the standing crop). Note that $\mathrm{C}_{\text {org }}$ and $\Delta^{14} \mathrm{C}$ profiles and model-calculated downward velocities refer to the "nonsoluble" fraction of the soil carbon reservoir (see EXPERIMENTAL METHODS). Translocation of dissolved organic material by organic complexing and readsorption on mineral surfaces, influencing soil organic matter formation at least at $\mathrm{M} 3$ (podsolization at soil $\mathrm{pH} \simeq 3.5$ ), is supposedly not observable from our ${ }^{14} \mathrm{C}$ data. It is not obvious from the data to what extent the higher soil $\mathrm{pH}$, higher annual input and the disequilibrium between input and decomposition account for the faster downward movement of soil organic matter at M1 and M2.

Generally, downward velocities of $0.6-1.6 \mathrm{~mm} / \mathrm{yr}$ in the uppermost soil layers are slightly higher than what is expected from ${ }^{14} \mathrm{C}$ ages of several thousand years at $1 \mathrm{~m}$ depth in Mollisols (Scharpenseel et al, 1986). This could be an indication for 1) reduced downward velocity in deeper soil layers, 2) increased soil carbon standing crop and deposition rate in the past 25 years due to anthropogenic excess $\mathrm{CO}_{2}$ in the atmosphere and increased nutrient input to the soil, and 3) influence of bioturbation on ${ }^{14} \mathrm{C}$ depth distribution (Scharpenseel et al, 1986). The question whether transport velocities obtained from the displacement of the bomb ${ }^{14} \mathrm{C}$ peak in the upper $10 \mathrm{~cm}$ can be compared with ${ }^{14} \mathrm{C}$ dates in various other soils at $1 \mathrm{~m}$ depth needs further investigation.

\section{${ }^{210} \mathrm{~Pb}$ TRANSPORT IN THE SOIL}

${ }^{210} \mathrm{~Pb}$, a member of the natural ${ }^{238} \mathrm{U}$ decay series with a half-life of 22.3 $\mathrm{yr}$, is produced by $\alpha$-decay of ${ }^{222} \mathrm{Rn}$ via some short-lived ${ }^{222} \mathrm{Rn}$ daughter products. The noble gas ${ }^{222} \mathrm{Rn}\left(\mathrm{t}_{1 / 2}=3.8\right.$ days $)$ is produced in the soil by $\alpha$-decay of ${ }^{226} \mathrm{Ra}$ and diffuses out of the soil into the atmosphere. In the soil air or in the atmosphere ${ }^{222} \mathrm{Rn}$ decays to ${ }^{210} \mathrm{~Pb}$, the atmospheric ${ }^{210} \mathrm{~Pb}$ is attached to the atmospheric aerosol and eventually is deposited on the soil surface by wet or dry deposition. In the soil, the atmospheric ${ }^{210} \mathrm{~Pb}$ contribution (excess ${ }^{210} \mathrm{~Pb}, \Delta^{210} \mathrm{~Pb}$ ) can be distinguished from the in-situ-produced ${ }^{210} \mathrm{~Pb}$ by measuring the ${ }^{226} \mathrm{Ra}$ activity, assumed to be in radioactive equilibrium with its daughter products. The loss of soil-borne ${ }^{210} \mathrm{~Pb}$ due to loss of ${ }^{222} \mathrm{Rn}$ to the atmosphere is estimated from measured ${ }^{222} \mathrm{Rn}$ fluxes. The determination of excess ${ }^{210} \mathrm{~Pb}$ in soil profiles is described in detail by Graustein and Turekian (1986). 


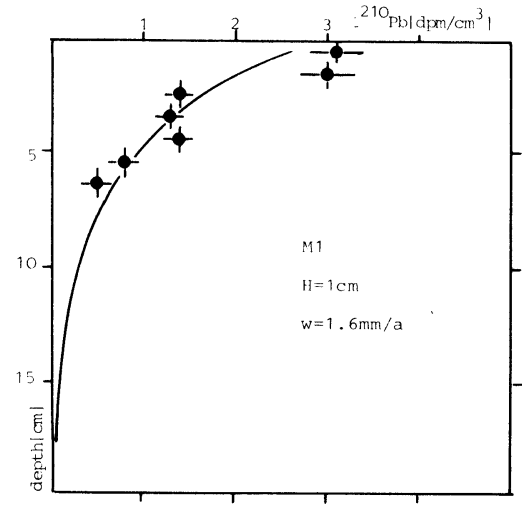

Fig 3A. Depth distribution of ${ }^{210} \mathrm{~Pb}$ at $\mathrm{M} 1$ and the calculated profile. Model parameters are given in the diagram.

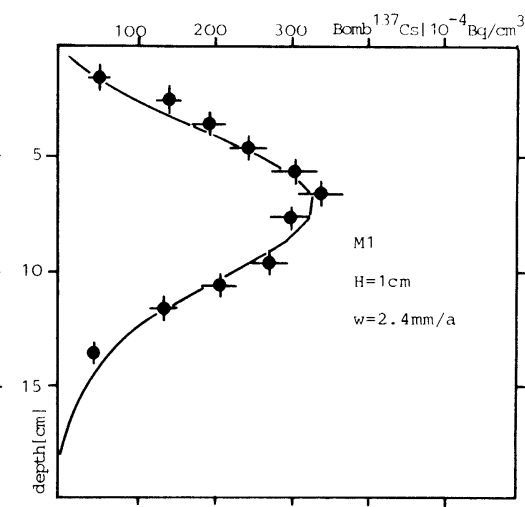

Fig 3B. Depth distribution of bomb ${ }^{137} \mathrm{Cs}$ at M1 and the calculated profile. Model parameters are given in the diagram.

Figure $3 \mathrm{~A}$ shows the depth distribution of excess ${ }^{210} \mathrm{~Pb}$ at $\mathrm{M} 1$ together with the calculated profile obtained from the same model as used for the $\mathrm{C}_{\text {org }}$ and $\Delta^{14} \mathrm{C}$ profiles, assuming a time constant input of ${ }^{210} \mathrm{~Pb}$ to the soil. The excess ${ }^{210} \mathrm{~Pb}$ activity decreases exponentially with depth due to radioactive decay during penetration into deeper soil layers. In practice, the downward velocity of ${ }^{210} \mathrm{~Pb}$ is obtained more easily from the relaxation depth of the profile, ie, the depth at which the activity has decreased to $\mathrm{e}^{-1}$ of the surface activity and from the mean life of ${ }^{210} \mathrm{~Pb}$. The observed downward velocities of ${ }^{210} \mathrm{~Pb}$ range between $0.5 \mathrm{~mm} / \mathrm{a}$ and $1.6 \mathrm{~mm} / \mathrm{a}$.

Identical ${ }^{210} \mathrm{~Pb}$ and organic matter downward velocities at M1, M2, M3 and $\mathrm{M} 4$ ( $\mathrm{cf} \mathrm{w}_{\mathrm{org}}, \mathrm{w}_{\mathrm{Pb}}$ in Table 1) indicate that the lead transport is due to the downward movement of soil organic matter itself. Identical ${ }^{210} \mathrm{~Pb}$ velocities in sandy (M1 and M3) and in clayey or loamy soils (M2 and M4) show that in organic rich soil, the mineral soil particle grain size is of minor importance for the mobility of lead. Likewise, mobilization of lead at lower soil $\mathrm{pH}$ is not observed. At neutral to weakly alkaline soil $\mathrm{pH}\left(\mathrm{M} 1\right.$ and $\mathrm{M} 2{ }^{210} \mathrm{~Pb}$ velocity is even higher than in acid soil $(\mathrm{pH}=3.5$ at M3).

\section{BOMB ${ }^{137}$ CS TRANSPORT IN THE SOIL}

${ }^{137} \mathrm{Cs}$ entered the atmosphere in the early 1960 s by nuclear weapon testing. ${ }^{137} \mathrm{Cs}$ and ${ }^{210} \mathrm{~Pb}$ attach to similar-sized aerosols in the atmosphere (Graustein \& Turekian, 1986) and are removed by the same processes. Deposition of bomb ${ }^{137}$ Cs was maximal in 1963/1964.

Figure 3B shows the depth distribution of bomb ${ }^{137} \mathrm{Cs}$ at $\mathrm{M} 1$, the calculated profile obtained from the same model used for $\mathrm{C}_{\mathrm{org}}, \Delta{ }^{14} \mathrm{C}$ and ${ }^{210} \mathrm{~Pb}$ profiles, and the known bomb ${ }^{137} \mathrm{Cs}$ input function. The ${ }^{137} \mathrm{Cs}$ depth profile is corrected for ${ }^{137} \mathrm{Cs}$ deposited after the reactor accident in Chernobyl in 1986 with ${ }^{134} \mathrm{Cs}$ measurements and the known ${ }^{137} \mathrm{Cs} /{ }^{134} \mathrm{Cs}$ ratio of the Chernobyl fallout (Dörr \& Münnich, 1987b). 
The ${ }^{137} \mathrm{Cs}$ downward migration velocity is obtained from model calculation or more easily from the penetration depth of the bomb ${ }^{137} \mathrm{Cs}$ maximum and the time elapsed since the deposition. Observed downward velocities of ${ }^{137} \mathrm{Cs}$ range between $0.8 \mathrm{~mm} / \mathrm{a}$ and $3.3 \mathrm{~mm} / \mathrm{a} .{ }^{137} \mathrm{Cs}$ velocities at sites M1 to M4 are listed in Table 1.

${ }^{137} \mathrm{Cs}$ velocities are plotted $v{ }^{210} \mathrm{~Pb}$ velocities (Fig 4) observed at various locations in south Germany. Assuming ${ }^{210} \mathrm{~Pb}$ transport is due to the downward movement of soil organic matter $\left(\mathrm{w}_{\mathrm{Pb}}=\mathrm{w}_{\mathrm{org}}\right)$, Figure 4 indicates that migration of ${ }^{137} \mathrm{Cs}$ is similarly influenced by turnover and downward movement of soil organic matter. Linear regression, however, gives $\mathbf{w}_{\mathrm{Cs}}=$ $0.6+2 \mathrm{w}_{\text {org/pb. }}$. The offset at $\mathrm{w}_{\text {org }}=0$ and the slope of $\mathrm{m}=2$ show that cesium is not exclusively transported by the downward movement of solid organic material. Rather, it travels faster than organic matter due to chemical exchange between the organic and hydrous phase. Identical ${ }^{137} \mathrm{Cs}$ velocities in sandy soils (M1 and M3) and in clayey and loamy soils (M2 and M4) indicate that in organic-rich soils, as for ${ }^{210} \mathrm{~Pb}$, ion exchange on mineral soil particles is of minor influence. Again, ${ }^{137} \mathrm{Cs}$ does not seem to be mobilized by low soil $\mathrm{pH}$. On the other hand, laboratory experiments (Tegen, 1988) suggest that mobilization of cesium in organic-rich forest soils is mainly due to the production of dissolved organic carbon (DOC).

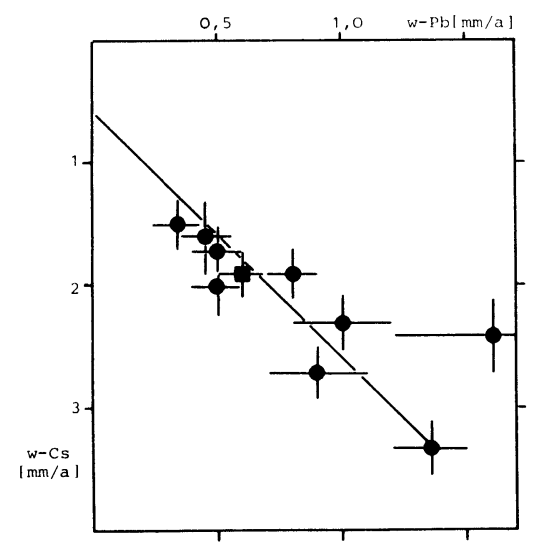

Fig 4. Downward velocity of ${ }^{137} \mathrm{Cs} v s$ downward velocity of ${ }^{210} \mathrm{~Pb}$ obtained at various locations in southern Germany. Linear regression yields an offset of $\mathrm{w}_{\mathrm{Cs}, \mathrm{o}}=0.6 \mathrm{~mm} / \mathrm{a}$ and a slope of $\mathrm{m}=2$.

\section{CONCLUSIONS}

The data presented show that the turnover and downward movement of soil organic material can be described by a box-chain model. The contribution of the fast and slowly decomposable carbon reservoir to the total soil $\mathrm{CO}_{2}$ production is estimated from inspection of the annual litter fall. This could be a convenient tool to estimate the ${ }^{14} \mathrm{C}$ content of soil respiration $\mathrm{CO}_{2}$ on a more global scale. 
Downward migration of the "non-soluble" fraction of soil organic matter is found to be faster in soils with high carbon turnover and high soil $\mathrm{pH}$. Reduced microbial activity in soils with low $\mathrm{pH}$ leads to lower downward velocities. This supports the assumption that downward movement is combined with aging of soil organic matter, because only sufficiently small and, thus, old particles can percolate into deeper soil layers (Dörr \& Münnich, 1986).

Identical downward migration velocities of organic material and ${ }^{210} \mathrm{~Pb}$ at soil $\mathrm{pH}$ between $\mathrm{pH}=8(\mathrm{M} 2)$ and $\mathrm{pH}=3.5$ (M3) suggest that lead transport is due to the downward movement of the soil organic material itself. Likewise, migration of ${ }^{137} \mathrm{Cs}$ seems to be more influenced by the turnover and downward movement of soil organic material than by soil $\mathrm{pH}$ and mineral grain size. More investigation of soil organic carbon, ${ }^{210} \mathrm{~Pb}$ and ${ }^{137} \mathrm{Cs}$ transport in various soils and ecosystems is needed to draw general conclusions.

\section{ACKNOWLEDGMENTS}

This study was funded by the State Government of Baden-Württemberg (FRG), grant no. PW85009. We are grateful to B Kromer for ${ }^{14} \mathrm{C}$ dates, and Ch Hecht and K H Grosser for sampling and experimental work.

\section{REFERENCES}

Dörr, H, Kromer, B and Münnich, K O, 1988, Fast ${ }^{14} \mathrm{C}$ sample preparation of organic material: This issue.

Dörr, H and Münnich, K O, 1987a, Annual variation in soil respiration in selected areas of the temperate zone: Tellus, v 39B, p 114-121. $1987 \mathrm{~b}$, Spatial distribution of soil ${ }^{137} \mathrm{Cs}$ and ${ }^{134} \mathrm{Cs}$ in West Germany after Chernobyl: Naturwissenschaften, v 74, p 249-251.

1986, Annual variation of the ${ }^{14} \mathrm{C}$ content of soil $\mathrm{CO}_{2}$, in Stuiver, $\mathrm{M}$ and $\mathrm{Kra}, \mathrm{R}$ $\mathrm{S}$, eds, Internatl ${ }^{14} \mathrm{C}$ conf, 12 th, Proc: Radiocarbon, v 28, no. $2 \mathrm{~A}, \mathrm{p} 338-345$.

Graustein, W C and Turekian, K K, $1986,{ }^{210} \mathrm{~Pb}$ and ${ }^{137} \mathrm{Cs}$ in air and soils measure the rate and vertical profile of aerosol scavenging: Jour Geophys Research, v 91, no. D13, p 14.35514.366.

Harkness, D D, Harrison, A F and Bacon, P J, 1986, The temporal distribution of bomb ${ }^{14} \mathrm{C}$ in a forest soil, in Stuiver, $\mathrm{M}$ and $\mathrm{Kra}, \mathrm{R} \mathrm{S}$, eds, Internatl ${ }^{14} \mathrm{C}$ conf, 12 th, Proc: Radiocarbon, v 28, no. 2A, p 328-337.

Levin, I, Kromer, B, Schoch-Fischer, H, Bruns, M, Münnich, M, Berdau, D, Vogel, J C and Münnich, K O, 1985, 25 years of tropospheric ${ }^{14} \mathrm{C}$ observations in central Europe: Radiocarbon, v 27, no. 1 , p 1-19.

O'Brien, B J, 1986, The use of natural and anthropogenic ${ }^{14} \mathrm{C}$ to investigate the dynamics of soil organic carbon, in Stuiver, $\mathrm{M}$ and $\mathrm{Kra}, \mathrm{R} \mathrm{S}$, eds, Internatl ${ }^{14} \mathrm{C}$ conf, 12th, Proc: Radiocarbon, v 28, no. $2 \mathrm{~A}, \mathrm{p} 358-362$.

O'Brien, B J and Stout, J D, 1978, Movement and turnover of soil organic matter as indicated by carbon isotope measurements: Soil Biol Biochem, v 10, p 309-317.

Scharpenseel, H W, Tsutsuki, K, Becker-Heidmann, P and Freytag, J, 1986, Untersuchungen zur Kohlenstoffdynamik und Bioturbation von Mollisolen: Zeitschr Pflanzenernaehr Bodenk, v 149, p 582-597.

Tegen, I, (ms) 1988, Laborexperimente zur Tiefenverlagerung von Caesium: Diplomarbeit, Inst f Umweltphysik, Univ Heidelberg. 